\title{
Tick-borne pathogens and associated co-infections in ticks collected from domestic animals in central China
}

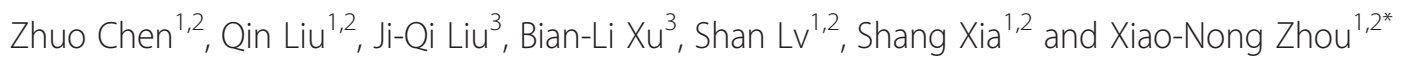

\begin{abstract}
Background: Ticks can transmit a number of pathogens to humans and domestic animals. Tick borne diseases (TBDs), which may lead to organ failure and death have been recently reported in China. $98.75 \%$ of the total cases (>1000) in Henan provinces have been reported in Xinyang city. Therefore, the aims of this study were to investigate the fauna of ticks and detect the potential pathogens in ticks in Xinyang, the region of central China.

Methods: Ticks were collected from 10 villages of Xinyang from April to December 2012, from domestic animals including sheep, cattle and dogs. Then identification of ticks and detection of tick-borne pathogens, including Babesia spp., Theileria spp., Anaplasma spp., Ehrlichia spp., Rickettsia spp., tick-borne encephalitis virus (TBEV), Borrelia burgdorferi sensu lato, Leishmania infantum, were undertaken by using polymerase chain reaction assay (PCR) and sequence analysis. Moreover, the co-infection patterns of various pathogens were compared among locations where ticks were collected.
\end{abstract}

Results: A total of 308 ticks were collected. Two species of Ixodidae were found, namely Haemaphysalis longicornis (96.75\%) and Rhipicephalus microplus (3.25\%). Five genera of pathogens, namely Theileria spp. (3.25\%), Anaplasma spp. (2.92\%), Babesia spp. (1.95\%), Ehrlichia spp. (2.92\%) and Rickettsia spp. (0.65\%), were detected in 7 villages. Co-infections by two pathogens were diagnosed in $11.11 \%$ of all infected ticks.

Conclusions: Both human and animal pathogens were abundant in ticks in the study areas. Humans and animals in these regions were at a high risk of exposure to piroplasmosis, since piroplasm had the highest rates of infection and co-infection in positive ticks.

Keywords: Ticks, Domestic animals, Tick-borne pathogens, Co-infections, China

\section{Background}

Ticks (Acari: Ixodida) are parasitic acari that suck blood from their vertebrate hosts [1]. They can transmit a number of pathogenic organisms to humans and domestic animals $[2,3]$ and cause a variety of important natural focal diseases and zoonoses. Ticks are important pests and vectors of several pathogens in tropical and subtropical regions [4-6].

\footnotetext{
* Correspondence: zhouxn1@chinacdc.cn

${ }^{1}$ National Institute of Parasitic Diseases, Chinese Center for Disease Control and Prevention, Shanghai 200025, People's Republic of China

${ }^{2}$ Schistosomiasis and Filariasis; Key Laboratory of Parasite and Vector Biology, Ministry of Health, WHO Collaborative Center for Malaria, Shanghai 200025,

People's Republic of China

Full list of author information is available at the end of the article
}

To date, more than 900 species of ticks have been recorded globally, with two major families, namely Ixodidae and Argasidae, the former generally referred to as hard ticks and the later also known as soft ticks [7]. In China, about eleven genera of ticks have been recorded which covered approximately 120 species, including 10 species of Argasidae and over 100 species of Ixodidae [8]. Tick species were specific in different zones in China [9].

There were ten major tick-borne diseases reported in China, such as Tick-borne encephalitis (Forest encephalitis, TBE), Q-fever, Oriental spotted fever, North-Asia tickborne spotted fever, Crimean-Congo hemorrhagic fever (Xinjiang hemorrhagic fever), Colorado fever, Tick-borne relapsing fever, Lyme borreliosis, tularemia and piroplasmosis. These diseases were mostly reported in northern 
and northeastern China in areas such as Xinjiang, Inner Mongolia, Heilongjiang, Jilin, Liaoning and Yunnan provinces [10].

The distribution of ticks and tick-borne pathogens varied in different provinces in China with uneven distribution in space and time. Lyme borreliosis is caused by Borrelia burgdorferi sensu lato. The first human case of Lyme borreliosis was reported in a forest region of Heilongjiang province in 1985 [11]. Up to date, human borreliosis cases have been confirmed in 29 provinces and 19 provinces have been indicated to be the natural foci. TBE, caused by the TBE virus (TBEV), was first reported in 1952 in China [12] and now mainly occurs in mountainous areas and forest regions of north China, such as Heilongjiang, Jilin, Xinjiang, Inner Mongolia. Q-fever, caused by the infection with Coxiella burnetii, is distributed in more than 20 provinces. The first case was discovered in 1950 in China and outbreaks occurred in Inner Mongolia, Sichuan, Xinjiang, Yunnan and Tibet [13]. Piroplasmosis caused by Babesia and Theileria infections were endemic in livestock in Qinghai, Gansu, Ningxia, Sichuan and Yunnan provinces [11]. However, human babesiosis is rarely reported in China. The first suspected case of human babesiosis was reported in 1982 in Yunnan province [14]. In 2012, a middle-aged woman in Zhejiang Province was reported infected with Babesia microti [15]. Although few human cases were also reported in Inner Mongolia and Taiwan [16,17], the epidemiological and transmission characteristics of babesiosis were unclear.

Human granulocytic anaplasmosis (HGA), an emerging infectious disease in China, is caused by Anaplasma phagocytophilum. The first human case of HGA was reported in Anhui province in 2006 [18], and then a series outbreaks occurred in Anhui, Tianjin, Shandong, Heilongjiang, Xinjiang and Hainan [19]. More recently, several outbreaks of TBDs, which may lead to organ failure and death have been reported in the central regions of China since 2007 [20]. Until 2011, more than 1000 cases had been reported in Henan province, and $98.75 \%$ cases were in Xinyang city and mainly occurred between April to October [21]. Most of patients were farmers and residents in the mountainous or hilly villages with history of tick bites [22]. In 2010, a new virus, isolated from blood samples of such patients from Henan province, was named as the severe fever with thrombocytopenia syndrome virus (SFTSV), which became another emerging TBD in China [23].

It has been reported that one tick species can transmit a variety of pathogens, and several kinds of TBDs often co-exist in the same natural foci [24]. Therefore, if humans or animals were bit by ticks with co-infections, it could result in a more complicated pathogenicity and worse prognosis. The potential threats of emerging pathogens as well as their co-infections due to the local social economic development and alteration of the natural environment will pose high risks to human health. For instance, the number of patients with fever of unknown origin is on the rise at peak activity period of ticks. This provides the hypothesis that there could be some unknown pathogens or co-infections in local ticks. Therefore, we investigated the fauna of ticks and potential pathogens and co-infections in Xinyang city which aimed to achieve a better understanding of distribution of tick species and tick-borne pathogens in central China.

\section{Methods}

\section{Ethical clearance}

Ethical and institutional approval documents were given by National Institute of Parasitic Diseases, Chinese Center for Disease Control and Prevention.

\section{Tick collection and identification}

An investigation was conducted from April to December 2012 in 10 different villages located in 8 counties and 2 districts in Xinyang (Figure 1). The collection sites were determined by a method of random grid sampling, which was performed in ArcGIS. Ticks were collected once in each sampling site from the skin of domestic animals including sheep, cattle and dogs. The number of ticks collected from each individual animal was not more than 15 . Ticks were counted and grouped according to their developmental stage. The species were identified based on morphologic criteria [25]. The specimens were kept frozen at $-20^{\circ} \mathrm{C}$ with RNAlater RNA Stabilization Reagent (Qiagen, Germany) and used for further molecular identification and detection of tick-borne pathogens.

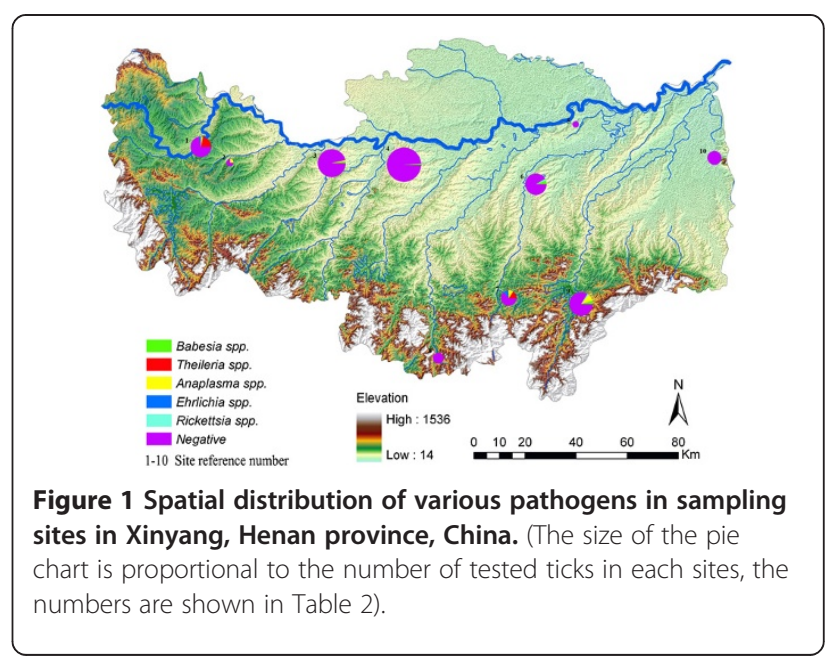




\section{DNA and RNA extraction}

Ticks were individually crushed with liquid nitrogen and plastic homogenizer using AllPrep DNA/RNA Mini Kit (Qiagen, Germany) for DNA and RNA extraction according to the handbook's instructions. cDNA was synthesized from freshly extracted total RNA immediately by reverse transcription using OneStep RT-PCR Kit (Qiagen, Germany) also followed the handbook's instructions. DNA, RNA and cDNA of ticks were stored at $-80^{\circ} \mathrm{C}$ until use.

\section{PCR amplification and sequencing}

In this study, each tick specimen was screened by PCR for both identification of tick species and detection of pathogens including Babesia spp., Theileria spp., Leishmania infantum, Anaplasma spp., Ehrlichia spp., Rickettsia spp., tick-borne encephalitis virus (TBEV) and Borrelia burgdorferi sensu lato. The tick species were confirmed by PCR using specific primers $16 \mathrm{~S}+1$ (5' -CCGGTCTGAACTCAGATCAAGT-3') and 16S-1 (5'-CTGCTCAATGA TTTTTTA AATTGCTGTGG-3') [26]. One step PCR was used to detect $L$. infantum [27]. Nested PCR was used for detection of Babesia spp., Theileria spp., Anaplasma spp., Ehrlichia spp., Rickettsia spp., B. burgdorferi s. $l$. and TBEV with protocols described in the references [28-32]. The target genes, specific primers, PCR methods used for testing different pathogens are listed in Table 1. Aliquot of double distilled water were included in all PCR runs to detect contamination. All PCR were carried out on a C1000 Touch $^{\text {TM }}$ Thermal Cycler (BIO-RAD, USA). PCR products were sent to Sangon Biotech (Shanghai, China) for sequencing in both directions. Sequences in this study were compared with sequences available in the NCBI database by BLAST analysis.

\section{Statistical analysis}

Differences in the numbers of collected ticks and positive rates of pathogens in different animal species and terrain types were tested by $\chi^{2}$-test, which was performed in SPSS 18.0.

\section{Results}

Tick identification

A total of 308 ticks were collected in 10 villages (range 3-89 ticks per site). Only two tick species were sampled. Both were Ixodidae. The most abundant species was $H$. longicornis (96.75\%). The other one was $R$. microplus (3.25\%). $298 \mathrm{H}$. longicornis had been collected from all hosts species in all 10 villages, but only $10 R$. microplus were collected from sheep and cattle in 3 villages (sampling

Table 1 Target genes, primers sequence, PCR methods used for pathogens identification

\begin{tabular}{|c|c|c|c|c|c|}
\hline Pathogens & Method & Target gene & Primers sequence $\left(5^{\prime}-3^{\prime}\right)$ & Product size (bp) & Reference \\
\hline \multirow[t]{4}{*}{ Babesia/Theileria } & Nested PCR & $18 \mathrm{~S}$ rRNA & RIB-19(CGGGATCCAACCTGGTTGATCCTGC) & 1700 & [28] \\
\hline & & & RIB-20(CCGAATTCCTTGTTACGACTTCTC) & & \\
\hline & & & BAB-F(ACCTCACCAGGTCCAGACAG) & 430 & \\
\hline & & & BAB-R(GTACAAAGGGCAGGGACGTA) & & \\
\hline \multirow[t]{4}{*}{ Anaplasma/Ehrlichia } & Nested PCR & $16 \mathrm{~S}$ rRNA & Eh-out1 (TTGAGAGTTTGATCCTGGCTCAGAACG) & 653 & [29] \\
\hline & & & Eh-out2 (CACCTCTACACTAGGAATTCCGCTATC) & & \\
\hline & & & Eh-gs1 (GTAATACTGTATAATCCCTG) & 282 & \\
\hline & & & Eh-gs2 (TATAGGTACCGTCATTATCTTCCCTAC) & & \\
\hline \multirow[t]{4}{*}{ TBEV } & Nested PCR & Non-structural protein NS5 & FSM1 (GAGGCTGAACAACTGCACGA) & 357 & [32] \\
\hline & & & FSM2 (GAACACGTCCATTCCTGATCT) & & \\
\hline & & & FSM1i (ACGGAACGTGACAAGGCTAG) & 251 & \\
\hline & & & FSM2i (GCTTGTTACCATCTITGGAG) & & \\
\hline \multirow[t]{4}{*}{ Rickettsia spp. } & Nested PCR & groEL & Gro1 (AAGAAGGCGTGATAAC) & 200 & {$[30]$} \\
\hline & & & Gro2 (ACTTCCGTAGCACC) & & \\
\hline & & & SF (GATAGAAGAAAAGCAATGATG) & 250 & \\
\hline & & & SR (CAGCTATTTGAGATTTAATTTG) & & \\
\hline \multirow[t]{4}{*}{ B. burgdorferi s. I. } & Nested PCR & Flagellin & Outer1 (CTGCTGGCATGGGAGTTTCT) & 730 & {$[31]$} \\
\hline & & & Outer2 (TCAATTGCATACTCAGTACT) & & \\
\hline & & & Inner1 (AAGGAATTGGCAGTTCAATC ) & 290 & \\
\hline & & & Inner2 (ACAGCAATAGCTTCATCTTG ) & & \\
\hline \multirow[t]{2}{*}{ Leishmania infantum } & $P C R$ & kDNA & RV1 (CTTTTCTGGTCCCGCGGGTAGG) & 183 & [27] \\
\hline & & & RV2(CCACCTGGCCTATTTTACACCA) & & \\
\hline
\end{tabular}


site 1,4 and 5 ). The majority of collected ticks were adult (female $86.69 \%$, male $6.82 \%$ ). Only a few of nymphs $(5.84 \%)$ and larvae $(0.65 \%)$ were sampled.

\section{Pathogen detection and identification}

Babesia spp., Theileria spp., Ehrlichia spp., Anaplasma spp. and Rickettsia spp. were detected in 7 villages, and the positive rates were $1.95 \%, 3.25 \%, 0.97 \%, 2.92 \%$ and $0.65 \%$, respectively. TBEV, B. burgdorferi s. $l$. and $L$. infantum were not detected in any ticks. There was no positive tick found in three villages (sampling sites 5, 8 and 10).

Piroplasms were the most frequently detected pathogen, the positive rate was $5.19 \%$. The prevalence of detected pathogens in each sampling site was shown in Table 2 and Figure 1. In this study, four Theileria (T. sergenti, T. orientalis, T. buffeli and T. luwenshuni) and three Babesia (B. gibsoni, B. canis vogeli and B. microti) species were identified. A. phagocytophilum, Rickettsia sp. and Ehrlichia sp. were detected. The sequences of detected pathogens in this study were deposited in GenBank, and the GenBank accession numbers are shown in Table 3.

Overall, $8.77 \%$ of ticks were tested positive for at least one pathogen. $8.72 \%$ of $H$. longicornis and $10 \%$ of $R$. microplus were detected positive. All the pathogens were detected in H. longicornis, and only one pathogen (Theileria spp.) was detected in $R$. microplus. The overall prevalence of pathogens in larvae, nymphs and adult ticks were $0.00 \%, 5.56 \%$ and $9.03 \%$, respectively. There was no significant difference in the prevalence of these pathogens among different developmental stages of ticks (all $P>0.05$ ). However, there were significant differences in prevalence of these pathogens among host species and terrain types. Prevalence of these pathogens in ticks collected from sheep, dogs and cattle were 9.23\%, 4.17\% and $26.47 \%$, respectively. The positive rate of pathogens in ticks collected from cattle was 2.87 times $\left(\chi^{2}=7.17\right.$, $\mathrm{df}=1, P<0.05)$ and 6.35 times $\left(\chi^{2}=17.73, \mathrm{df}=1, P<0.05\right)$ more than that from sheep and dogs, respectively. Prevalences of these pathogens in ticks in mountainous, hilly and plain areas were $20.56 \%, 2.03 \%$ and $3.77 \%$, respectively. The positive rate of pathogens in ticks collected from mountainous area was 5.45 times $\left(\chi^{2}=7.83, \mathrm{df}=1\right.$, $\mathrm{P}<0.05)$ and 10.14 times $\left(\chi^{2}=24.12, \mathrm{df}=1, \mathrm{P}<0.05\right)$ more than that from plain and hilly areas respectively. The results are displayed in Table 4.

\section{Co-infections}

Out of 27 positive ticks, 3 ticks (11.11\%) were found coinfected with two pathogens. One co-infection detected was B. microti (KJ715163) with Rickettsia sp. (KJ715194) in one $H$. longicornis tick collected from a dog in sampling site 6. The other two co-infections were T. luwenshuni (KJ715167) with Ehrlichia sp. (KJ715196) and T. luwenshuni (KJ715168) with A. phagocytophilum (KJ715199) in two $H$. longicornis ticks which were both collected from sheep in sampling site 7.

\section{Spatial distribution}

The spatial distribution of pathogens is shown in Figure 1. The prevalence and diversity of pathogens were much higher in the middle elevation regions, which mostly were mountainous areas (sampling site 1,2,7 and 9). Relatively, there were lower prevalence rates and fewer species of pathogens detected in low elevation regions, which mostly were plain or hilly areas (sampling site 3,4,5,6 and 10) as well as in the high elevation region, which is mountain top area (sampling site 8). The geographical locations of co-infections were adjacent to each other (sampling site 6 and 7).

\section{Discussion}

Xinyang city is located at the sub-tropical region of China. The western, southern and central regions are mountainous or hilly areas, and the north regions are plain areas (Figure 1). Relatively high humidity and temperature during the summer provide a suitable environment for the development and reproduction of ticks.

In this study, we found that $H$. longicornis was the dominant tick species in Xinyang which didn't have any host specificity. These results are consistent with previous studies [33-36], which suggested that $H$. longicornis could play an important role as the reservoir host for various pathogens and the source of disease in this area.

Table 2 Prevalence of detected pathogens in different sampling site

\begin{tabular}{|c|c|c|c|c|c|c|c|c|c|c|c|}
\hline \multirow{2}{*}{$\begin{array}{l}\text { Detected } \\
\text { pathogens }\end{array}$} & \multicolumn{11}{|c|}{ Positive ticks and prevalence of pathogens in each sampling site } \\
\hline & $\begin{array}{c}1 \\
(n=32)\end{array}$ & $\begin{array}{c}2 \\
(n=4)\end{array}$ & $\begin{array}{c}3 \\
(n=59)\end{array}$ & $\begin{array}{c}4 \\
(n=89)\end{array}$ & $\begin{array}{c}5 \\
(n=3)\end{array}$ & $\begin{array}{c}6 \\
(n=35)\end{array}$ & $\begin{array}{c}7 \\
(n=19)\end{array}$ & $\begin{array}{c}8 \\
(n=9)\end{array}$ & $\begin{array}{c}9 \\
(n=43)\end{array}$ & $\begin{array}{c}10 \\
(n=15)\end{array}$ & $\begin{array}{c}\text { Total } \\
(\mathrm{n}=\mathbf{3 0 8})\end{array}$ \\
\hline Babesia spp. & 0 & 0 & $1(1.69 \%)$ & $1(1.12 \%)$ & 0 & $2(5.71 \%)$ & 0 & 0 & $2(4.65 \%)$ & 0 & $6(1.95 \%)$ \\
\hline Theileria spp. & $7(21.88 \%)$ & 0 & 0 & 0 & 0 & 0 & $3(15.79 \%)$ & 0 & 0 & 0 & $10(3.25 \%)$ \\
\hline Anaplasma spp. & $1(3.13 \%)$ & $1(25.00 \%)$ & $1(1.69 \%)$ & 0 & 0 & 0 & $2(10.53 \%)$ & 0 & $4(9.30 \%)$ & 0 & 9 (2.92\%) \\
\hline Ehrlichia spp. & 1 (3.13\%) & 0 & 0 & 0 & 0 & 0 & $2(10.53 \%)$ & 0 & 0 & 0 & $3(0.97 \%)$ \\
\hline Rickettsia spp. & 0 & 0 & 0 & 0 & 0 & $1(2.86 \%)$ & 0 & 0 & $1(2.33 \%)$ & 0 & $2(0.65 \%)$ \\
\hline
\end{tabular}


Table 3 Detected pathogens in ticks collected from different hosts in different locations, and GenBank accession numbers in this study

\begin{tabular}{|c|c|c|c|c|c|}
\hline \multicolumn{2}{|c|}{ Pathogens (No. positive) } & \multirow{2}{*}{$\frac{\text { Ticks species }}{\text { H.longicornis }}$} & \multirow{2}{*}{$\frac{\text { Animal species }}{\text { Cattle }}$} & \multirow{2}{*}{$\frac{\text { Sampling site No. }}{1}$} & \multirow{2}{*}{$\begin{array}{l}\text { GenBank accession No. } \\
\text { KJ715170, KJ715175 }\end{array}$} \\
\hline Theileria & T. buffeli (2) & & & & \\
\hline & T. sergenti (3) & H.longicornis & Cattle & 1 & KJ715171, KJ715173, KJ715174 \\
\hline & T. orientalis (1) & H.longicornis & Cattle & 1 & KJ715172 \\
\hline & T. luwenshuni (3) & H.longicornis & Sheep & 7 & KJ715167- KJ715169 \\
\hline \multirow[t]{3}{*}{ Babesia } & B. canis vogeli (3) & H.longicornis & Sheep, Dog & $3,4,9$ & KJ715161, KJ715164, KJ715165 \\
\hline & B. gibsoni (2) & H.longicornis & Dog & 6,9 & KJ715162, KJ715166 \\
\hline & B. microti (1) & H.longicornis & Dog & 6 & KJ715163 \\
\hline Rickettsia & Rickettsia sp. (2) & H.longicornis & Sheep, Dog & 6,9 & KJ715194, KJ715195 \\
\hline Ehrlichia & Ehrlichia sp. (3) & H.longicornis & Sheep, Cattle & 1,7 & KJ715196- KJ715198 \\
\hline Anaplasma & A. phagocytophilum (9) & H.longicornis & Sheep, Dog, Cattle & $1,2,3,7,9$ & KJ715199- KJ715207 \\
\hline
\end{tabular}

Only a few $R$. microplus were collected in this study, but its distribution was similar to previous studies $[37,38]$. Moreover, previous study documented the existence of O. lahorensis and I. persulcatus in this area [39], however no samples of $O$. lahorensis and I. persulcatus were collected in this study. This could be attributed to only one transmission season as well as the limited number of host species that were taken into account.

The results of this study have demonstrated two interesting facts about infections in ticks which were correlated to the impacts of local environment and social activities.
First, the positive rates of pathogens in ticks were significantly higher in the mountainous areas than those in the plain areas. This is probably because of the diversity and larger population size of host animals in mountainous areas. Second, the positive rate of ticks was significantly higher in ticks collected from cattle and sheep. This situation is potentially related to local animal husbandry. In fact, sheep husbandry was more common in the rural area, but most farmers rarely neutralized parasites and sheepfolds were kept close to the villagers' house for the purpose of anti-theft. It was reported in the Henan

Table 4 Comparison of the differences of collected ticks and positive rates of pathogens among ticks life stage, host species and terrain types

\begin{tabular}{|c|c|c|c|c|c|c|c|c|}
\hline \multirow{2}{*}{\multicolumn{2}{|c|}{ Groups }} & \multirow{3}{*}{$\begin{array}{c}\text { Sampled ticks } \\
\mathbf{N} \\
2\end{array}$} & \multicolumn{2}{|c|}{ Positive ticks } & \multirow{3}{*}{$\begin{array}{c}x^{2} \\
0.12\end{array}$} & \multirow{3}{*}{$\begin{array}{c}\text { DF } \\
1\end{array}$} & \multirow{3}{*}{$\begin{array}{c}\text { RR }(95 \% \mathrm{Cl}) \\
-\end{array}$} & \multirow[t]{2}{*}{$P$} \\
\hline & & & \multirow{2}{*}{$\begin{array}{l}\mathbf{n} \\
0\end{array}$} & \multirow{2}{*}{$\begin{array}{c}\% \\
0.00\end{array}$} & & & & \\
\hline Life stage & Larvae & & & & & & & 0.7324 \\
\hline & Nymphs & 18 & 1 & 5.56 & & & - & \\
\hline & Larvae & 2 & 0 & 0.00 & 0.20 & 1 & - & 0.6561 \\
\hline & Adult & 288 & 26 & 9.03 & & & - & \\
\hline & Nymphs & 18 & 1 & 5.56 & 0.25 & 1 & 1.00 & 0.6144 \\
\hline & Adult & 288 & 26 & 9.03 & & & $1.62(0.23-11.30)$ & \\
\hline \multirow[t]{6}{*}{ Terrain feature } & Hilly & 148 & 3 & 2.03 & 24.12 & 1 & 1.00 & 0.0000 \\
\hline & Mountainous & 107 & 22 & 20.56 & & & $10.14(3.12-33.02)$ & \\
\hline & Hilly & 148 & 3 & 2.03 & 0.49 & 1 & 1.00 & 0.4836 \\
\hline & Plain & 53 & 2 & 3.77 & & & $1.86(0.32-10.84)$ & \\
\hline & Plain & 53 & 2 & 3.77 & 7.83 & 1 & 1.00 & 0.0051 \\
\hline & Mountainous & 107 & 22 & 20.56 & & & $5.45(1.33-22.31)$ & \\
\hline \multirow[t]{6}{*}{ Hosts } & Dogs & 144 & 6 & 4.17 & 2.85 & 1 & 1.00 & 0.0911 \\
\hline & Sheep & 130 & 12 & 9.23 & & & $2.22(0.86-5.73)$ & \\
\hline & Dogs & 144 & 6 & 4.17 & 17.73 & 1 & 1.00 & 0.0000 \\
\hline & Cattle & 34 & 9 & 26.47 & & & $6.35(2.42-16.64)$ & \\
\hline & Sheep & 130 & 12 & 9.23 & 7.17 & 1 & 1.00 & 0.0074 \\
\hline & Cattle & 34 & 9 & 26.47 & & & $2.87(1.32-6.24)$ & \\
\hline
\end{tabular}

$\mathrm{DF}=$ degrees of freedom; $\mathrm{RR}=$ risk ratio; $\mathrm{Cl}=$ confidence interval. 
Statistical Yearbook 2012 that a total of 818.4 thousands of sheep were raised in Xinyang. Therefore, all these factors could pose high risks of exposure to humans resulting in human infections with those pathogens.

Overall, Anaplasma spp. and Babesia spp. were distributed in continuous areas with overlapped regions. The other three pathogens were distributed in separate foci respectively. This is the first report of Rickettsia spp. in ticks collected from domestic animals in this region. $R$. typhii and spotted fever group rickettsiae had been detected in rodents caught in this area [40], although no human cases have been reported yet. In fact, human ehrlichiosis (HE) had been clinical diagnosed in local farmers that had evidence of tick bites in Xinyang [41]. This finding suggested that Xinyang would potentially be an endemic area of human ehrlichiosis.

The positive rate of Theileria spp. was especially high in ticks collected from cattle and sheep. Given that theileriosis was endemic in animals in Henan province [42,43], as well as in other regions $[44,45]$, it could pose a high risk of exposure and infection to livestock and increase the economic burden on the breeding industry and farmers in this region. Although Babesia spp. infection rate was not the highest in this region, it is still higher than in other areas [46]. The positive rate was higher in ticks sampled from dogs, and similar result was reported in Thailand [47]. In this study, we found one tick infected with B. canis vogeli which was collected from a sheep, and one tick infected with B. microti which was collected from a dog. Generally speaking, B. canis vogeli infections were often detected in dogs, and so far there were no reports about its infection in sheep. These findings warrant further studies. However, B. microti had been detected in many kinds of wild and domestic animals including dogs, and could be the cause of human babesiosis as well. Babesiosis had been detected in livestock in China including Henan province [48-53], and human babesiosis had been diagnosed in some province in mainland China recent years [54,55]. Although there has been no report of human babesiosis in Xinyang yet, we suspected that some cases have been misdiagnosed as Plasmodium infection [56], since Plasmodium spp. was once heavily endemic in this area [57,58]. It would be even more difficult to differentiate Babesia spp. from Plasmodium spp. when a co-infection had occurred.

A new finding was that Babesia spp. co-infected with Rickettsia spp. in ticks in Xinyang region. The results also indicated that Theileria spp. might be more likely to co-exist with other pathogens in ticks. The spatial distribution of those pathogens suggested that humans and animals in the region were at the higher risk of exposures to co-infections.

In recent years, great progress had been made on identification of tick-borne disease (TBD) vectors, hosts and evaluating the impacts of TDBs to humans. However, it's still necessary to carry out more studies on co-infections. So far as we know, there were only several reports documented that $B$. burgdorferi s. $l$. co-infected with other pathogens in ticks in north-eastern China where Lyme disease is known to be endemic [59-62]. Ticks co-infected with multiple pathogens greatly increased the risk of coinfections to humans, which would result in more complex clinical manifestation and could be misdiagnosed. Although there was no reports of co-infections of tickborne pathogens in humans in China as of yet, great concern had been raised because the pathogens might share common tick vectors and reservoir hosts, which means transmission of co-infections to humans could be quite possible.

\section{Conclusions}

Both human and animal pathogens occur in ticks in the study areas. Most of the tick species lack host specificity [63]. The impacts of global climate change, increased population mobility, decreased natural host populations, host-switching behavior of ticks [64] could lead to the outbreaks and endemic of tick-borne zoonoses once these public health threats transfer to humans. Further studies are needed to estimate the impacts to local residence and animal husbandry by these vectors and pathogens and to establish effective measures to control the vector ticks.

\section{Competing interests}

The authors declare that they have no competing interests.

\section{Authors' contributions}

ZC conducted field sampling, performed tick species identification and the laboratory work, generated experimental data, and wrote the manuscript. QL and X-NZ had a substantial role in conception of the study, guidance of the practical work and writing the manuscript. J-QL and B-LX helped with sample collection. SL and SX helped with statistical analysis and contributed to the manuscript. All authors read and approved the manuscript.

\section{Acknowledgements}

This work was supported by the Special Fund for Health Research in the Public Interest (Grant No. 201202019). Authors would like to thank all the colleagues in Henan provincial CDC, Xinyang city CDC and 10 counties/districts CDCs who helped with collection of ticks.

\section{Author details}

${ }^{1}$ National Institute of Parasitic Diseases, Chinese Center for Disease Control and Prevention, Shanghai 200025, People's Republic of China.

${ }^{2}$ Schistosomiasis and Filariasis; Key Laboratory of Parasite and Vector Biology, Ministry of Health, WHO Collaborative Center for Malaria, Shanghai 200025, People's Republic of China. ${ }^{3}$ Henan Center for Disease Control and Prevention, Zhengzhou 450016, People's Republic of China.

Received: 4 March 2014 Accepted: 6 May 2014

Published: 22 May 2014

\section{References}

1. Nava S, Guglielmone AA, Mangold AJ: An overview of systematics and evolution of ticks. Front Biosci (Landmark Ed) 2009, 14:2857-2877.

2. Blancou J, Chomel BB, Belotto A, Meslin FX: Emerging or re-emerging bacterial zoonoses: factors of emergence, surveillance and control. Vet Res 2005, 36:507-522

3. Cunningham AA: A walk on the wild side-emerging wildlife diseases. BMJ 2005, 331:1214-1215. 
4. Jongejan F, Uilenberg G: The global importance of ticks. Parasitology 2004, 129(Suppl 1):3-14.

5. Hotez PJ, Savioli L, Fenwick A: Neglected tropical diseases of the middle east and north Africa: Review of their prevalence, distribution, and opportunities for control. PLOS Negl Trop Dis 2012, 6:e1475

6. Jensenius M, Parola P, Raoult D: Threats to international travellers posed by tick-borne diseases. Travel Med Infect Dis 2006, 4:4-13.

7. Barker SC, Murrell A: Systematics and evolution of ticks with a list of valid genus and species names. Parasitology 2004, 129(Suppl 1):15-36.

8. Liu Q, Wang WL, Meng QF: Research progress of ticks and tick-borne disease. J Anhui Agri Sci 2013, 41:1107-1109.

9. Yang XJ, Chen Z, Yang XH, Liu JZ: Principal component and cluster analysis for different host types of chinese ticks. Sichuan J Zool 2008, 27:824-826.

10. Fu FX, Guo W, Zhang Y, Ding F, Tang F: Advances in epidemiological research on tick borne infectious diseases. Inter J Epidemiol Infect Dis 2012, 39:285-288.

11. Meng XH, Liu ZJ, Huang FS: Ticks in China such as Lyme disease media research situation. Health Helminthic Machinery 2004, 3:137-140.

12. Ma XY, Peng WM, Gao X: Progress in research of tick-borne encephalitisvirus. Chin J Virol 2004, 20:190-192.

13. Zhou JP, Zhang WY, Ju HB: Tick and tick-borne infectious diseases Shanghai J Anim Hus Vet Med 2011, 4:52-53.

14. He DM, Wang YM: Progress in research of human babesiosis. Chin J Infect Dis 2012, 30:638-640.

15. Yao LN, Ruan W, Zeng CY, Li ZH, Zhang X, Lei YL, Lu QY, Che HL: Pathogen identification and clinical diagnosis for one case infected with Babesia. Chin J Parasitol Parasit Dis 2012, 30:118-121.

16. Wu JJ, Zhou JL: Progress on Babesiosis. Prog Vet Med 2013, 34:173-178.

17. Shih CM, Liu LP, Chung WC, Ong SJ, Wang CC: Human babesiosis in Taiwan: asymptomatic infection with a Babesia microti-like organism in a Taiwanese woman. J Clin Microbiol 1997, 35:450-454.

18. Zhang L, Liu Y, Ni D, Li Q, Yu Y, Yu XJ, Wan K, Li D, Liang G, Jiang X, Jing $H$, Run J, Luan M, Fu X, Zhang J, Yang W, Wang Y, Dumler JS, Feng Z, Ren J, $\mathrm{Xu}$ J: Nosocomial transmission of human granulocytic anaplasmosis in China. JAMA 2008, 300:2263-2270.

19. Gao D, Cao W, Zhang $X$ : Investigations on Human ehrlichia infectious people in Daxingan Mountains. Chin J Epidemiol 2001, 22:137-141.

20. Kang $K$, Tang $X Y, X u$ BL, You AG, Huang XY, Du YH, Wang HF, Zhao GH, Chen HM, Liu GH, Meng FJ: Analysis of the epidemic characteristics of fever and thrombocytopenia syndrome in Henan province, 2007-2011. Chin J Prev Med 2012, 46:106-109.

21. Liu Y, Huang $X Y$, Du YH, Wang HF, Xu BL: Survey on ticks and detection of new bunyavirus in some vector in the endemic areas of fever thrombocytopenia and leukopenia syndrome (FTLS) in Henan province. Chin J Prev Med 2012, 46:500-504

22. Xu B, Liu L, Huang X, Ma H, Zhang Y, Du Y, Wang P, Tang X, Wang H, Kang K, Zhang S, Zhao G, Wu W, Yang Y, Chen H, Mu F, Chen W: Metagenomic analysis of fever, thrombocytopenia and leukopenia syndrome (FTLS) in Henan Province, China: discovery of a new bunyavirus. PLoS Pathog 2011, 7:e1002369.

23. Lam TTY, Liu W, Bowden TA, Cui N, Zhuang L, Liu K, Zhang YY, Cao WC, Pybus OG: Evolutionary and molecular analysis of the emergent severe fever with thrombocytopenia syndrome virus. Epidemics 2013, 5:1-10.

24. Labuda M, Nuttall PA: Tick-borne viruses. Parasitology 2004 129(Suppl 1):221-245.

25. Lu BL, Wu HY: Classification and Identification of Important Medical Insects of China. Zhengzhou: Henan Science and Technology Publishing House; 2003.

26. Krakowetz CN, Lindsay LR, Chilton NB: Genetic diversity in Ixodes scapularis (Acari: Ixodidae) from six established populations in Canada. Ticks Tick Borne Dis 2011, 2:143-150.

27. le Fichoux Y, Quaranta JF, Aufeuvre JP, Lelievre A, Marty P, Suffia I, Rousseau D, Kubar J: Occurrence of Leishmania infantum parasitemia in asymptomatic blood donors living in an area of endemicity in southern France. J Clin Microbiol 1999, 37:1953-1957.

28. Silveira JA, Rabelo ÉM, Lacerda AC, Borges PA, Tomás WM, Pellegrin AO, Tomich RG, Ribeiro MF: Molecular detection and identification of hemoparasites in pampas deer (Ozotoceros bezoarticus Linnaeus, 1758) from the Pantanal Brazil. Ticks Tick Borne Dis 2013, 4:341-345.

29. Wen B, Jian R, Zhang Y, Chen R: Simultaneous detection of Anaplasma marginale and a new Ehrlichia species closely related to Ehrlichia chaffeensis by sequence analyses of $16 \mathrm{~S}$ ribosomal DNA in Boophilus microplus ticks from Tibet. J Clin Microbiol 2002, 40:3286-3290.

30. Zhang L, Ni D, Feng Z: External quality assessment of the detection of rickettsioses in China. Asian Pac J Trop Med 2010, 3:851-854

31. Huppertz HI, Schmidt H, Karch H: Detection of Borrelia burgdorferi by nested polymerase chain reaction in cerebrospinal fluid and urine of children with neuroborreliosis. Eur J Pediatr 1993, 152:414-417.

32. Puchhammer-Stöckl E, Kunz C, Mandl CW, Heinz FX: Identification of tick-borne encephalitis virus ribonucleic acid in tick suspensions and in clinical specimens by a reverse transcription-nested polymerase chain reaction assay. Clin Diagn Virol 1995, 4:321-326.

33. Chen Z, Yang XJ, Yang XH, Liu JZ: Geographical distribution and fauna of chinese ticks. Sichuan J Zool 2008, 5:38.

34. Ren YD, Shen XC, Sun H, Ma XJ: The fauna element and geographical distribution of insect, spider and mite in Henan, China. Acta Agri Bore Sin 2011, 1:43

35. Wan K, Zhang Z, Dou G: Investigation on primary vectors of Borrelia Burgdorferi in China. Chin J Epidemiol 1998, 19:263-266.

36. Yin H, Luo J: Ticks of small ruminants in China. Parasitol Res 2007, 101(Suppl 2):187-189.

37. Qin XC, Tian JH, Wang JB, Lu X, Sun QZ, Jin D, Zhou DJ, Xu JG, Zhang YZ: Identification of Haemaphysalis longicornis and Rhipicephalus microplus. Chin J Epidemiol 2011, 32:608-612.

38. Chen Z, Yang X, Bu F, Yang X, Yang X, Liu J: Ticks (acari: ixodoidea: argasidae, ixodidae) of China. Exp Appl Acarol 2010, 51:393-404.

39. Zhang WL, Bao YD, Li ZY, Fu FX, Chen ZH, Shen DX, Tang F, Li ZD: Related investigation on prevalence of tick-borne diseases in Shangcheng area, Henan. Inter J Epidemiol Infect Dis 2011, 38:171-175.

40. Fu XP, Zhang JS, Shen XJ, Luan MC, Li ML, Zhang LJ: Surveillance on Rickettsia in epidemic areas of scrub typhus in Xinyang areas of Henan province. Chin J Epidemiol 2007, 28:547-549.

41. Tian J, He Y, Wei P, Li W, Jie SH, Yao JH: Retrospective analysis of clinical diagnosis of 21 cases of human ehrlichiosis. Chin J Infect Dis 2010, 28:278-281

42. Yin H, Schnittger L, Luo J, Seitzer U, Ahmed JS: Ovine theileriosis in China: a new look at an old story. Parasitol Res 2007, 101(Suppl 2):191-195.

43. Luo J, Lu W: Cattle theileriosis in China. Trop Anim Health Pro 1997, 29(Suppl):4-7.

44. Luo J, Yin H: Theileriosis of sheep and goats in China. Trop Anim Health Pro 1997, 29(Suppl):8-10

45. Yin H, Luo J, Guan G, Gao Y, Lu B, Zhang Q, Ma M, Lu W, Lu C, Yuan Z, Guo S, Wang B, Du H, Schnittger L, Ahmed J, Jongejan F: Transmission of an unidentified Theileria species to small ruminants by Haemaphysalis qinghaiensis ticks collected in the field. Parasitol Res 2002, 88(Suppl 1):25-27.

46. Wen J, Zhao G, Jiao D, Wang JH, Wang XD, Wang GZ, Shi XJ: Investigation on tick-borne pathogens at China-Russia border in Heihe city. Acta Parasitol Med Entomol Sin 2013, 20:42-46.

47. Ahantarig A, Trinachartvanit W, Milne JR: Tick-borne pathogens and diseases of animals and humans in Thailand. Southeast Asian J Trop Med Public Health 2008, 39:1015-1032.

48. Liu AH, Yin H, Guan GQ, Schnittger L, Liu ZJ, Ma ML, Dang ZS, Liu JL, Ren QY, Bai Q, Ahmed JS, Luo JX: At least two genetically distinct large Babesia species infective to sheep and goats in China. Vet Parasitol 2007, 147:246-251.

49. Luo J, Yin H, Guan G, Zhang Q, Lu W: Description of a new Babesia sp. infective for cattle in China. Parasitol Res 2002, 88(Suppl 1):13-15.

50. Schnittger L, Yin H, Qi B, Gubbels MJ, Beyer D, Niemann S, Jonejan F, Ahmen JS: Simultaneous detection and differentiation of Theileria and Babesia parasites infecting small ruminants by reverse line blotting. Parasitol Res 2004, 92:189-196.

51. Bai Q, Liu G, Liu D, Ren J, Li X: Isolation and preliminary characterization of a large Babesia sp. from sheep and goats in the eastern part of Gansu Province, China. Parasitol Res 2002, 88(1):16-21.

52. Wang WB, Liu ZB, Bao XJ, Liu WC, Ye JH: Epidemiological investigation of ticks (Ixodida) on police dogs in some areas of China. Chin J Vet Med 2013, 49:17-20.

53. Liu Q, Zhou YQ, Zhou DN, Liu EY, Du K, Chen SG, Yao BA, Zhao JL: Semi-nested PCR detection of Babesia orientalis in its natural hosts Rhipicephalus haemaphysaloides and buffalo. Vet Parasitol 2007, 143:260-266.

54. Su GG, Zhao NF, Ye YX: Babesiosis report. Chin J Zoonoses 2012, 18:112 
55. Zhou X, Li SG, Chen SB, Wang JZ, Xu B, Zhou HJ, Zhu GHX, Chen JH, Hu W: Co-infections with Babesia microti and Plasmodium parasites along the China-Myanmar border. Infect Dis Poverty 2013, 2:24.

56. Centeno-Lima S, Do Rosario V, Parreira R, Maia AJ, Freudenthal AM, Nijhof AM, Jongejan F: A fatal case of human babesiosis in Portugal: molecular and phylogenetic analysis. Trop Med Int Health 2003, 8:760-764

57. Liu XZ, Xu BL: Malaria situation and evaluation on the control effect in Henan Province during 1990-2005. Chin J Parasitol Parasit Dis 2006 , 24:226-229

58. Liu Y, Qian D, Deng Y, Su YP: Analysis of malaria in Henan Province in 2010. J Pathog Bio 2011, 12:015.

59. Yang LW, Hou Y, Li M, Wen ZQ, Yang J, Fan DH: Study of tick-borne pathogens at Heilongjiang Port. Chin Frontier Health Quarantine 2007, 30:77-82.

60. Huang HN, Ding Z, He J, Wu XM, Jiang BG, Gao Y, Chu CY, Zhan L, Zhao QM, Wang YF, Cao WC: Study on the coinfection status of Borrelia burgdorferi sensu lato and spotted fever group Rickettsia in ticks from Hunchun, Jilin province. Chin J Epidemiol 2006, 27:379-383.

61. Li Y, Kang FY, Yang JF, Sun CQ, Liu ZJ, Yin H: Prevalence and coexistence of Anaplasma phagocytophilum and Borrelia burgdorferi sensu lato in ticks in Gansu, Hunan and Guangdong provinces, China. Chin J Zoonoses 2013, 29:117-121.

62. Meng Z, Jiang LP, Lu QY, Cheng SY, Ye JL, Zhan L: Detection of co-infection with Lyme spirochetes and spotted group richettsiae in a group of Haemaphysalis longicornis. Chin J Epidemiol 2008, 29:1217-1220.

63. Dick CW, Patterson BD: Against all odds: explaining high host specificity in dispersal-prone parasites. Int J Parasitol 2007, 37:871-876.

64. Huyse T, Poulin R, Theron A: Speciation in parasites: a population genetics approach. Trends Parasitol 2005, 21:469-475.

doi:10.1186/1756-3305-7-237

Cite this article as: Chen et al.: Tick-borne pathogens and associated co-infections in ticks collected from domestic animals in central China. Parasites \& Vectors 2014 7:237.

\section{Submit your next manuscript to BioMed Central and take full advantage of:}

- Convenient online submission

- Thorough peer review

- No space constraints or color figure charges

- Immediate publication on acceptance

- Inclusion in PubMed, CAS, Scopus and Google Scholar

- Research which is freely available for redistribution 